\title{
Determination of pasture infestation with tick larvae
}

\begin{abstract}
Rhipicephalus microplus tick infestations in livestock cause the world's largest ectoparasite problem in tropical and subtropical regions. The fight against ticks must also be carried out taking into account aspects related to the presence of non-parasitic stages in the grass. The integral management of ticks as a control method and the appropriate combination of its components can focus on breaking the balance of these larval populations, which are mainly found in grazing. Basic larval tick population sampling systems have been used for direct manual harvesting from vegetation. The most widely used method has been dragging. The objective of this work is to determine, by means of dragging methods with the flag method, the infestation of the larval stage of ticks, under natural conditions of pasture infestation. The study will be carried out in pastures with an area of 26 hectares, dedicated to grazing, divided into 7 pastures of 3 hectares, where a herd of cattle is exploited. The samples will be obtained crossing the zigzag zone and randomly. In the pastures, transects were drawn along them, the samplings will be carried out during the month of June. From the paddocks reviewed, tick larvae were collected only in two of the 7 reviewed, 91 larvae in one and 6 larvae in another. The larvae were identified as Rhipicephalus microplus.
\end{abstract}

Volume 8 Issue 6 - 2020

\author{
Alier Fuentes Castillo, Yaima Armenteros \\ Zardivar \\ 'Laboratorio Nacional de Parasitología, Deparment of \\ Ectoparasitología, Universidad Agraria de la Habana, Cuba
}

Correspondence: Alier Fuentes Castillo, Laboratorio Nacional de Parasitología. Autopista San Antonio de los baños km. I 1 12 San Antonio de los Baños, Artemisa, Cuba, Tel +53 5484I272, Email alierfuentesc115@gmail.com

Received: November 24, 2020 | Published: December 15, 2020

\section{Introduction}

Infestations of the Rhipicephalus microplus tick, in cattle, produce the greatest global problem of ectoparasites in tropical and subtropical regions, causing great economic losses in bovine production. The fight against ticks must also be conducted taking into account aspects related to the presence of non-parasitic stages in the grass. The integral management of ticks as a control method and the appropriate combination of its components can focus on breaking the balance of these populations of larvae, which is mainly found in grazing. ${ }^{1}$

In order to establish a control method on the R. microplus tick, it is essential to have a program that determines the presence of the phases, both parasitic in the host and non-parasitic in pastures; $;^{2-5}$ For this, safe and consistent population sampling methods are required. The initial procedure in this program would be to determine the partial population curve of the larval stage of $R$. microplus in the pastures. ${ }^{6-8}$

Basic systems for sampling larval tick populations have been used for direct manual collection of vegetation. The most frequently used method has been dragging. ${ }^{9}$ It has been possible to establish that the larval population in the pastures estimated by trawl techniques can be correlated with the parasitic population on the host. ${ }^{10}$

In Mexico, the flag drag technique has been used; however, there are no comparative studies involving different techniques for sampling grasslands infested with the free-living larval stage of $R$. microplus. It is important to point out that ranchers must have a safe, practical, low variability methodology to determine the degree of infestation in pastures, before introducing livestock. ${ }^{11-14}$

The objective of this work is to determine, by dragging methods with the flag method, the infestation of the larval stage of ticks, under natural conditions of pasture infestation.

\section{Materials and methods}

The study will be carried out in pastures with an area of 26 hectares, dedicated to grazing, divided into 7 pastures of 3 hectares as averages each, with established grasslands of Mulato, Guinea, and Estrella grass as the predominant ones and among other pastures natural, where a herd of Holstein and Holstein F1 cattle is exploited. The paddocks are fenced with barbed wire, the samples will be obtained by crossing the area in a zigzag and randomly, using the flag method.

Flag technique; consisting of the use of a white cloth of $1.0 \mathrm{~m} \mathrm{x}$ $90 \mathrm{~cm}$, fixed to the transverse end of a wooden device in the shape of " $\mathrm{T}$ ". In the paddocks, transects were drawn along their length and width, leaving a corridor of about $50 \mathrm{~cm}$ between each transect. The samplings will be carried out during the month of June, at a time when it did not rain in more than 15 consecutive days. The collection of the larvae will be with the help of a magnifying glass and with an adhesive tape, where the larvae will be glued, identifying the tape with the number of the transect traveled, to perform the counting and identification in the laboratory.

\section{Results}

The investigation was conducted from June 18 to 24 . Of the 7 pastures reviewed, tick larvae were collected only in two (28\%), obtaining 91 larvae in one and 6 larvae in another, in the rest no tick larvae were collected (table 1).

Table I Findings of larvae in the review of the investigated pastures

\begin{tabular}{lll}
\hline Potrero & Larvae quantity & Identification \\
\hline 1 & 0 & - \\
2 & 0 & - \\
3 & 91 & R. microplus \\
4 (aéreas del Comedor) & 0 & - \\
5 (aéreas del Limón) & 0 & - \\
6 (Almacén) & 6 & R. microplus \\
7 (Finca Vita) & 0 & -
\end{tabular}

The larvae were identified as Rhipicephalus microplus. The pastures for grazing had a resting time between 3 and 5 months. For tick control in the herd in operation, the rotation of the paddocks was taken into account, taking into account the infested paddocks and 
using them strategically to avoid the infestation of the animals and maintain low levels of infestation in the animals.

\section{Conclusions}

Two infested pastures of the 7 that were studied were determined, diagnosing the larvae found as Rhipicephalus microplus.

\section{Acknowledgments}

None.

\section{Conflicts of interest}

Authors declare that there is no conflict of interest.

\section{References}

1. Jairo Faría Romero. Como controlar las moscas y garrapatas en ganadería regenerativa de forma orgánica. Veterinaria Argentina; 2017

2. Hector QR. Parasitology and parasitic diseases in domestic animals. 7th ed. Mexico: Interamericana; 1987. 464 p.

3. Schmitdmann TE. Ecologically based strategies for controlling ticks. 1st ed. London: Oxford University Press; 1993. 7-38 p.

4. Davey BR, Garza J, Thompson DG. Seasonal observations on the development and ovipositional capability of Boophilus annulatus and Boophilus microplus reared on bovines. J Med Entomol. 1982;19(1):2428

5. Camino LM. The development of an integrated pest management system of tick free living on pastures and parasitic on cattle. Ann Entomol Soc. 1981;74(5):507-511.
6. Zimmerman HR, Garris IG. Sampling efficiency of three dragging techniques for the collection of non parasitic Boophilus microplus (Acari: Ixodidae) Larvae in Puerto Rico. J Econom Entomot. 1985;78(3):627631.

7. Suthers WR, More House ED. The seasonal incidence of Ixodid ticks on cat in an elevated area of South Eastern Queen Island Australia. J Agric Res. 1972;23:195.

8. Barnard DR. Amblyomma americanum: Comparison of populations of ticks free living on pastures and parasitic on cattle. Ann Entomol Soc. 1981;74(5):507-511.

9. Spickelt AM, Horak IG, Braack LEO, et al. Dragsampling of free-living Ixodid lick in the Kruger National Park, Onder step. J Vet Res. 1991;58:27.

10. Wilkinson RP, Gregson DJ. Comparison of sampling methods for recording the numbers of Rocky Mountain wood ticks (Dermacentor andersom) on cattle and range vegetation during control experiments. Acarologia. 1985;26(2):131-139.

11. Solis SS. Ecología de Garrapatas en México. Memorias Seminario Internacional de Parasitología Animal. Asociación Mexicana de Parasitología Veteriniria SARH: Cuernavaca, Morelos. México; 1986. $256 \mathrm{p}$.

12. Fideicomiso Campaña Nacional Contra la Garrapata. Manual para el inspector: México; 1980. 36 p.

13. Falco CR, Durland F. The Use of carbon-dioxide baited tick traps for sampling Ixodes dammlni (ACARI:IXODIDADE). Acarologia. 1989;30(1):29-33.

14. Solis SS. Estudio de Amblyomma cajenenseen una zona de aridez transicional con un índice de 39 en Campeche. Tesis Licenciatura. Universidad Nacional Autónoma de México: México; 1976. 47 p. 